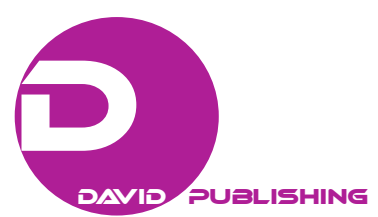

\title{
The Innovative Genius of Herod at Caesarea Maritima
}

\author{
Barbara Mary Denis Bergin \\ Independent Researcher, Dublin, Ireland
}

\begin{abstract}
Flavius Josephus records that Herod the Great created a harbour named Sebastos and a modern city called Caesarea. Archaeologists have been excavating the area now called Caesarea Maritima for decades. Here, Herod constructed a totally man-made port directly into the open sea, a totally revolutionary idea. He brought together architects, engineers, Roman master-builders, and Jewish artisans to construct his dream. His project was accomplished by the use of innovative Roman concrete which set quickly under water. It was immensely durable against the continued battering by the sea. Alongside he built a city surrounded by a protective wall, which comprised a temple, a unique terraced palace on an exposed site, a theatre, a hippo-stadium, and street system with aligned underground sewers. Herod brought together East and West, integrating the best of the traditions in a magnificent port-city. It became the centre of maritime trade between Rome and Alexandria. What remains of Herod's harbour is now underwater.
\end{abstract}

Keywords: imagination, innovation, building

\section{Introduction}

Powerful winds blow in from the west and strong currents make the waters treacherous but this is where Herod chose to create a new port-city known now as Caesarea Maritima and it became the crossroads of the ancient world. The centuries have worn away the splendour that once was, yet the ruins of the city still astonish the onlooker with their sheer magnitude. This article investigates these impressive ruins by examining the results produced by archaeologists, excavating over decades, and recognizing the innovative genius of King Herod.

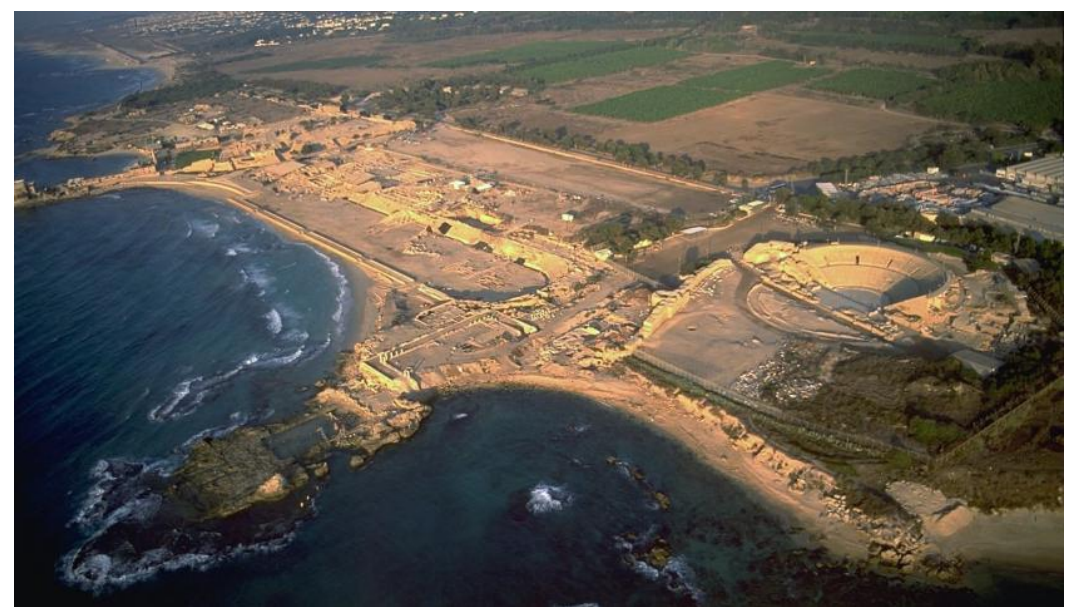

Figure 1. Caesarea Maritima (Source: Image from Accordance; Bible Study Software by AppleMac ${ }^{1}$ ).

\footnotetext{
Barbara Mary Denis Bergin, Independent Researcher, Dublin, Ireland.

${ }^{1}$ https://i.pinimg.com/736x/f8/2b/2a/f82b2a3ccdee1b800e96261ec31c5e94.jpg, Accessed on 10.9.2018
} 
Herod the Great was a client king of the Roman Empire. Although he was subordinate to the emperor he had great independence within his own realm. His father Antipater and his mother Cypros belonged to the elite and wealthy circle within the Hasmonean Court ${ }^{2}$, indeed Antipater was a powerful administrator under the Hasmonean Kings. Herod was brought up at court. In his formative years, the Hasmoneans were involved in construction projects that displayed inspiration and resourcefulness. They built palaces, fortresses, water supply systems, swimming pools, and agricultural installations (Netzer, 2006). Herod's mother came from Petra which was known for its exceptional building techniques.

When Herod was appointed king he brought peace to Palestine and it was natural that he would turn his energies to building. He had the power, wealth, imagination, and ingenuity to build on a monumental scale. Scholars around the world respect and acknowledge his design flair and building achievements throughout Judea and beyond. Herod was an innovative influence on structures created during his lifetime and his contribution was unique in the Greco-Roman world. This article is concerned with the revolutionary-type harbour at Sebastos and the city of Caesarea.

Scholars rely on the writings of Flavius Josephus as the starting point for information about Herod the Great. Archaeologists have found that he was accurate in his description of the buildings created by Herod but his numeric precision was not always as accurate (Burrell, 2014). Overall, the information in his writings has led archaeologists to the right geographical areas, in which to start their excavations and as a result our knowledge about the innovative construction techniques of Herodian buildings continues to be enhanced.

The approach in this article is to examine the writings of Flavius Josephus (Whiston, 1999), detailing the selection and building of Sebastos and Caesarea. The methodology is to take the information supplied by him in the Judean Wars (JW 1.21.408-415) and the Jewish Antiquities (JA 15.9.331-341) to investigate and compare his writings with what archaeologists have discovered, to support the author's hypothesis that Herod the Great brought his innovative genius to the building of Caesarea Maritima ${ }^{3}$.

Josephus describes how Herod selected the site and built the city

Now upon his observation of a place near the sea, which was very proper for containing a city, and was before called Strato's Tower, he set about getting a plan for a magnificent city there, and erected many edifices with great diligence all over it, and this of white stone. (JA 15.9.331)

\section{Promontory Palace}

It has been suggested that the unique palace that Herod built at Caesarea was constructed before any other buildings. The seaside climate would have been comfortable all year round. The king was an engineering genius but also a practical man. His continued use of local stone throughout his building schemes reflects this trait. Herod would have been enthusiastic to supervise this great port-city project and contribute his innovative ideas directly to the master builders. The palace itself was unique. Herod chose to build his palace on a rocky outcrop (Netzer, 2001). As with the great Northern Palace at Masada, he selected a site, on which to construct a palace that defied nature. Who would dare to build a palace out into the sea and face the might of the waves?

Herod created an original design, an intimate palace built from carved kurkar sandstone quarried locally. Following previous building experience at the many palaces constructed by him, Herod chose local stone which

\footnotetext{
2 The Hasmonean Dynasty ruled Judea before Herod the Great was appointed King by Caesar Augustus.

3 Josephus tells us that Herod decided to construct a harbour city with land donated to him by Octavian (later Augustus). The artificial harbor was called Sebastos (meaning Augustus) and the adjacent city was called Caesarea. Only much later did it come to be called Caesarea Maritima.
} 
was less expensive than importing great slabs of marble. Later, the building would be plastered and painted to take on the appearance of marble.

Josephus uses the word "basileia" which could be translated as one or many palace(s) (Netzer, 2008; Ovadiah \& Peleg, 2009). This structure has been called the Promontory Palace and was built first. The upper palace was constructed later and combined with the first. Perhaps, this is what Josephus meant.

The palace was $80 \mathrm{~m} \times 18 \mathrm{~m}$ approximately in size. It was a rectangular building with a peristyle area, the focal point of which was a rock-cut swimming pool $(35 \mathrm{~m} \times 18 \mathrm{~m} \times 2 \mathrm{~m})$ lined with hydraulic plaster, a compound used by Herod in all his swimming pools to prevent leakage. The pool was supplied by fresh ground water, available from areas along the coast which demonstrated an abundant flow of water. The water was gathered in cisterns and manually transferred to the pool. Columns and colonnades (cut from kurkar), divided with planted containers, created pleasant covered walkways $(2.6 \mathrm{~m}$ wide) for Herod and his guests to enjoy. This idea of an arcaded pavement with flowers is recognized as a Herodian innovation and numerous examples have been excavated in other palaces (Netzer, 2009). The main central area served as a triclinium, a large reception/dining room with a huge roman vaulted ceiling and was adorned with an intricate mosaic floor, which can still be seen today. The building had two floors, possibly with balconies overlooking the central pool. It would have been equipped with every luxury. It was a pioneering design carefully planned in every detail with "symmetry as one of the principles of its design" (Netzer, 1996, p. 198). The walls were very thick to withstand the force of the sea with no windows on the ground floor and the technology was the same as that used in the harbour (Netzer, 1996; Patrich, 2011). The walls were plastered and then painted to give a polished effect (Burrell, Gleason, \& Netzer, 1993; Fisher \& Stein, 1994).

The upper palace was added some years later before the official inaugural festivities for the opening of the port-city. This structure will be examined briefly later in this article (see page 388 ).

\section{Sebastos}

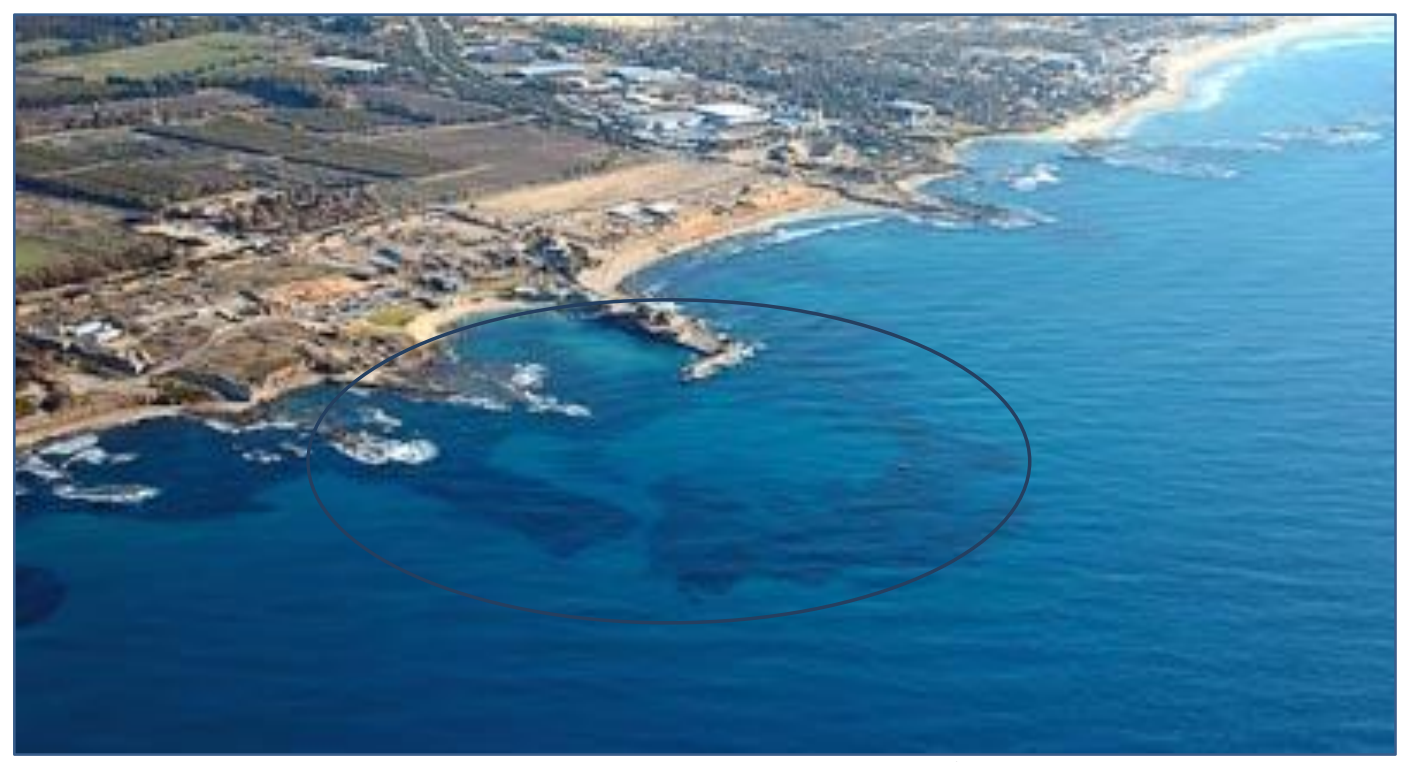

Figure 2. Remains of Sebastos Harbour ${ }^{4}$

\footnotetext{
${ }^{4}$ https://www.bibleplaces.com/, Accessed on 6.9.2018.
} 
What remains of the glorious harbour of Sebastos is now under water. At the tip of the breakwaters of the outer basin, there are huge blocks and the remains of the elaborate superstructures that crowned the harbour entrance. Archaeologists have been working here for decades to uncover the details of the structures that Herod created. There have been many archaeological expeditions and excavations at Caesarea Maritima (also called Caesarea Palaestinae) (Raban \&Holum, 1996) since 1959 including:

- The Link Expedition;

- The Missione Archaeologia Italiana;

- The Hebrew University;

- The American Expedition of Caesarea Maritima (JECM);

- The Israel Antiquities Authority (IAA);

- Israel Undersea Exploration Society;

- The Caesarea Ancient Harbour Excavation Project (CAHEP);

- The University of Pennsylvania;

- Combined Caesarea Expeditions (CCE);

- Caesarea Tourist Development Project;

- Roman Maritime Concrete Survey (ROMACONS).

These archaeological excavations on land and under the sea have created comprehensible scientific results detailing Herod's construction techniques in the first century B.C.E. at Caesarea Maritima. Information from the ROMACONS survey at Sebastos produced analysis from cores drilled on site which confirms the use of hydraulic concrete and the presence of pozzolana which could only have come from the Bay of Naples in Italy.

Josephus wrote his historiography after 70 C.E. His information on the actual construction techniques was secondhand. It is likely that he relied on the documentary evidence from Nicolaus of Damascus, Herod's court historian whose writings, except for a few fragments, have been lost to us. Josephus would have witnessed the structures created by Herod the Great as they were when the harbour was operating as a port. He tells us that Herod decided to build on a

seashore between Dora and Joppa, in the middle, between which this city is situated, had no good haven, insomuch that everyone that sailed from Phoenicia for Egypt was obliged to lie in the stormy sea, by reason of the south winds that threatened them; which wind, if it blew but a little fresh, such vast waves are raised, and dash upon the rocks, that upon their retreat the sea is in a great ferment for a long way. But the king, by the expenses he was at, and the liberal disposal of them, overcame nature, and built a haven larger than the Pyrecum [at Athens]; and in the inner retirements of the water he built other deep stations [for the ships also]. (JW 1.21.409-410)

Casearea Maritima is located between modern day Haifa and Tel-Aviv where powerful winds blow in from the west and strong currents make the waters treacherous. Sebastos must have been a magnificent sight: a huge harbour complex with three basins, the outer being the most innovative creation of Herod the Great with two semicircular breakwaters that protected the port from the rages of the sea. The two moles were a remarkable engineering achievement. This was the first time that a harbour was constructed directly out into the open sea. Herod was wealthy, driven, imaginative, innovative, and practical. He used these attributes to realize his dream of a port-city.

There were many obstacles to the successful building of Sebastos but Herod used his imaginative genius to bring together those who had the experience, knowledge of technology, and skill to create his innovative engineering masterpiece. There were many questions to be resolved before construction could start: 
1. Why did Herod select this site on such an exposed coastline?

2. Where could he obtain finance for this adventurous project?

3. Where to source suitably experienced craftsmen to carry out his ideas?

4. How could a massive structure be built out into the sea and how to mitigate the power of the sea so that the structures would survive?

5 . Where could the necessary raw materials be found?

6. How to solve the problem of the splash that would occur from the sea so that all goods could be unloaded and stored safely?

7. How to flush the three harbour basins and keep siltation to a minimum to maintain the depth in the harbour for seagoing vessels?

Why would Herod choose such a vulnerable coastline to build a harbour? It would become one of the principal ports of the Roman Empire. It became a safe haven from the swirling currents and severe storms of the Mediterranean. Herod wanted to prove that nature could be tamed by a unique and revolutionary approach to harbour building. He used the then derelict Strato's Tower, created by the Phoenicians and incorporated it into his magnificent harbour with three separate basins. Sebastos was unique and innovative. It was the first harbour to be built out into the open sea with no natural outcrops of rock, protective headlands or a sheltered bay to aid the construction of a port. It was totally man-made. It was an astonishing feat of revolutionary engineering that created the template for harbour building. The construction of Sebastos made it possible to build ports wherever it was politically, economically, and financially appropriate.

Where would the finance come from to support such a complicated project? Herod was financially secure. He had an immense private fortune and property. As the "legal" (Rome appointed) successor to the Hasmonean Kings he had taken over fiscal control of all their formerly owned fertile royal estates. Lands had been added to his portfolio by Augustus (Trachonitis, Batanaea Gaulanitis, and the confiscated district of Paneias) (Netzer, 2006). The olive groves at Jericho which had been under the control of Cleopatra were returned to him at this time. He supervised his family's properties in Idumea. He seized property from his opponents and Herod co-owned a copper mine which was extremely profitable. He used his wealth for lucrative business transactions (Schafer, 2003). His fortune was secure and he was prepared to put it to good use in creating a state of the art port-city in honour of his royal patron. Some scholars would disagree and point to financial support from Rome.

There is no written record of Herod asking permission from Augustus to build the port-city but it is unlikely that he would have been refused consent; after all, it was a tribute in concrete and stone to the emperor. The port was called Sebastos, meaning Augustus and Caesarea for Caesar. The entire project was funded by the King. Herod had been in Rome in 40 B.C.E. when the city was experiencing a vibrant building programme which may have inspired his imagination. Here, he met Marcus Agrippa who had dedicated both his organizational talent and his fortune to the rebuilding of the imperial city. ${ }^{5}$ The two became friends. This friendship would turn out to be crucial.

Where would Herod find suitable craftsmen to carry out his unique project? Within his own realm, he had a ready pool of Syro-Phoenician harbour builders with considerable knowledge of building and maintaining ports and havens on the Levantine coast (Raban, 2009). Many scholars believe now that Herod sourced a

\footnotetext{
5 G. W. Bowersock, Marcus Vispanius Agrippa, Enclyclopaedia Britannica Online at https://www.britannica.com/biography/Marcus-Vipsanius-Agrippa Accessed on 13.8.2018
} 
skilled labour force through Agrippa who would have had access to Roman master builders with all the technological experience needed for such a project (Hohlfelder, 2000). Herod brought together architects, engineers, and artisans from the Greco-Roman world and paired these with the genius and expertise of his Jewish builders to face the major challenge of building a monumental harbour out into the open sea.

Where could Herod source raw materials? There was plenty of local kurkar sandstone but there was a major problem in that there were no trees growing near the proposed site. Secondly, the necessary element for hydraulic concrete, pozzolana, was only available from the Bay of Naples in Italy, thus a major logistical snag confronted Herod. How to get the raw materials required to Palestine required a pioneering approach to logistics. Josephus reports that Herod travelled to Antioch regularly as a young man (JA XIV.440, 451; JW I.328512) and he had refurbished stadia and a stoa there (JA XXVI.148; JW.425) (Votruba, 2007). His reputation would have insured local cooperation. There is no documentary evidence of any arrangement between Agrippa and Herod that authorized the transport of timber (7,100 metric tonnes) (Votruba, 2007) from within the Mediterranean area or the shipment of pozzolana (20,000 metric tonnes) (Brandon, Hohlfelder, Jackson, \& Oleson, 2014) but the analysis of the timber used for the construction taken from the under-water formwork proves that the wood came from the southern shore of Turkey (Votruba, 2007). Examination of probes taken in Sebastos by the ROMACONS' Team and analysed in laboratories corroborates the supposition that pozzolana was imported from Puzzuoli in Italy (Hohfelder, Brandon, Jackson, \& Oleson, 2007).

How could the harbour be totally protected from the sea? Herod and his team had to consider a unique and inventive strategy to stop the splash from coming over the breakwaters. It would require a mechanism for dissipating the power of waves as they surged towards the harbour. Archaeologists have discovered moles strategically placed outside the main breakwaters that take the first onslaught of the waves. These structures were built as an integral part of the protection of the breakwaters, which could then deflect the splash once the power of the sea had been diminished. This innovative design had a second function. The sand laden waves were driven between the gaps of the protective moles; the sand was trapped between mole and breakwater and was pulled out by retreating waves.

The Levant is known for serious siltation problems within its harbours. As dredging was not possible at the time of Herod, he would have to find a way to flush out the harbour basins. The problem was solved by an innovative system. Shallow channels were cut into the main southern mole. The openings of the channels would face the surge, above sea level which would take the incoming water providing a constant inflow. In a wider area of the network it was possible to hold the sand free water which could be used to flush out the harbour. Sluice gates were provided to control the flow of water. When the collected water was released, it caused a current within the basins. All human waste and debris from the city and harbour was washed out to sea. Archaeologists have discovered evidence that supports the theory. Interestingly, in the main basin, after sifting through wave carried debris, archaeologists discovered a thin layer of mud that contains "first century sherds" (Raban, 1995). No sand was found in this layer therefore no siltation was present. The seabed outside the harbour revealed a large deposit ( $2 \mathrm{~m}$ thick) including all kinds of rubbish, waste, and junk carried out by the successful ancient flushing system (Raban, 1995).

\section{Harbour Construction}

Having worked through the major problems that confronted the harbour building project Herod set about creating the port. Josephus explains 
So Herod tried to rectify this inconvenience, and laid out such a boundary toward the land as might be sufficient for a harbour, wherein the great ships might lie in safety. (JA 1.21.6.334)

Archaeological excavation verifies what Josephus says that the major part of the deep water harbour, the outer basin, was built out into the sea formed by two massive moles that were intended to fill a dual function of breakwaters against the encroaching sea and as seawall that ran along the leeward side (Raban, 2009). Having resourced marine master builders, it was their task to decide how the moles should be built and what made Sebastos unique was the method of construction using hydraulic cement. The ancient Greeks first discovered this substance when a mixture of lime and volcanic ash was "slaked" a new compound was formed. The compound hardened quickly and was more durable than lime cement. The extraordinary strength and durability of this material, along with its ability to set underwater, made it a crucial component in Roman building. Vitruvius recommended the use of this compound in De Architectura which he wrote around this time (Hickey Morgan, 1914).

Herod's Roman master builders would have been involved on many projects, from which Vitruvius sourced information for his thesis. The builders were experienced architects, engineers, and artisans capable of producing innovative technology in Sebastos. Archaeology has confirmed that the harbour was constructed using revolutionary expertise. When Herod and his builders decided on a suitable design and method of building, the components were transported to the site. Josephus remarks that the harbour

was of excellent workmanship; and this was the more remarkable for its being built in a place that of itself was not suitable to such noble structures, but was to be brought to perfection by materials from other places, and at very great expenses. (JA 15.9.332)

The greatest single innovative building method utilised at Sebastos was the incorporation of Roman concrete into the two moles that stretched on either side of the deep-water harbour, without which such a project would have been impossible. Josephus describes the scene,

this he effected by letting down vast stones of above fifty feet in length, not less than eighteen in breadth, and nine in depth, into twenty fathom deep; and as some were lesser, so were others bigger than those dimensions. This mole which he built by the sea-side was two hundred feet, the half of which was opposed to the current of the waves, so as to keep off those waves which were to break upon them, and so was called Procymatia, or the first breaker of the waves; but the other half had upon it a wall, with several towers, the largest of which was named Drusus, and was a work of very great excellence, and had its name from Drusus, the son-in-law of Caesar, who died young. (JA 10.334-336)

The "stones" referred to above are great concrete blocks made using hydraulic concrete with its fundamental strength. It hardened under water in maritime conditions, and it had a robust quality. Herod was the first to introduce this revolutionary engineering technique into Palestine. How did his engineers work with this compound? This kind of concrete required the use of formwork, so that it could set securely underwater. Herodian builders used moulds made of wood called cassions. Herod's builders used their experience and expertise to design variations which were innovative and sophisticated to mitigate the difficulties that such an unprotected coastline presented (Raban \& Holum, 1996).

Archaeologists and engineers have uncovered evidence of the timber moulds used to form concrete blocks. It is surmised that islands were constructed first as working platforms at two strategic positions, one half way along the proposed southern breakwater and the other at the northern tip of the same mole (Raban, 2009). This

\footnotetext{
${ }^{6}$ Means that when the volcanic ash was mixed with water a chemical combination took place creating a new compound.
} 
was an inventive and effective solution to enable labourers, tools, and materials to work from a static structure and provide protection.

These islands were constructed from concrete blocks created from single use rectangular barges. This was a totally new concept. Shipwrights built the barges on shore which created a floating container with a floor. When the barge was launched it was partly filled with hydraulic concrete to ensure the bottom was sealed and then left to set and harden. The barges were $14 \mathrm{~m}$ long, $7 \mathrm{~m}$ wide, and $4 \mathrm{~m}$ in height. Since it was a "ship" design, it could be floated out to a predetermined area. The cofferdam was then anchored in position at each of the four corners and filled from tenders or barges with more concrete. As it was filled up, it gradually sank into position onto a rubble cushion. The sides were then supported with rubble to keep it in place and guard against the attack of the sea. Once on the seabed, the mould was topped off with the concrete mixture.

The cassions were sunk individually into a predetermined position and each mould was lowered as close to the other as possible. Any gaps between the cofferdams were filled with pozzolana packed sacks (Raban, 2009; Raban \& Holum, 1996; Martin, 2015; Brandon et al., 2014). The blocks were built into a solid platform. The single mission barges were an innovative design. This formwork was created by builders who had to face the raging waters of the open sea and the storms at Sebastos. An example of this floating structure was found at the end of the southern breakwater. Revolutionary and experimental ideas sprang from these challenges and man's ingenuity triumphed (Brandon et al., 2014).

Another innovative cassion design was discovered in Sebastos. This formwork could be built by shipwrights on shore as in the barge type cofferdam. This was an entirely different model. This was a floating box-like construction with no bottom but with a double planked exterior containment area "that acted like a collar" (Brandon et al., 2014, p. 212). An example of this innovative solution was discovered at the end of the northern breakwater. The advantage of this design was that it could be floated into position and sunk comfortably on the sandy seabed. As above it would have been anchored by chains. The exterior collar was filled with concrete and the cassion was lowered into position. Once settled on the bottom, rubble was piled against the sides to keep the formwork in place while the semi-liquid concrete was poured into the centre compartment of the cassion. This design is unique to Sebastos (Brandon et al., 2014).

Sunken concrete blocks formed the "spine" of the southern mole which extended for $300 \mathrm{~m}$ in westerly direction and then turned north to nearly double the length again up to approximately $500 \mathrm{~m}$ (Raban \& Holum, 1996). This outer wall was to form the breakwater against the sea. An inner wall (seawall) was constructed of carved ashlars built "in a tight course of headers" (Raban, 2009, p. 8). When the wall was completed to a level above the sea, it created a gap between the concrete blocks and the inner walls. This cavity was filled with sand brought by laden waves surging over the breakwater. This process would have taken time. Once sand filled the void, it was covered by a layer of rubble forming a base for laying slabs to create a pavement. Josephus says that piers, jetties, warehouses, and sleeping accommodation for sailors were built on the sheltered side of the breakwater but archaeologists have not discovered any remnants of vaults or warehouses!

The second mole which stretched towards the west at a right-angle to the shoreline, was known as the northern breakwater, and followed the same revolutionary construction techniques. The construction of this mole would have been easier as the area would have been semi-protected by the southern breakwater. It is likely that, in this case, the gap between the breakwater and the seawall was filled manually. It was an ingenius and courageous decision by Herod's builders to use this technique whether the sand was brought in by the waves or dumped manually (Brandon, 2008). These two breakwaters formed the outer basin of the harbour 
which was much larger than the other two basins. The inner basin was created from the ruins of the anchorage at Strato's Tower.

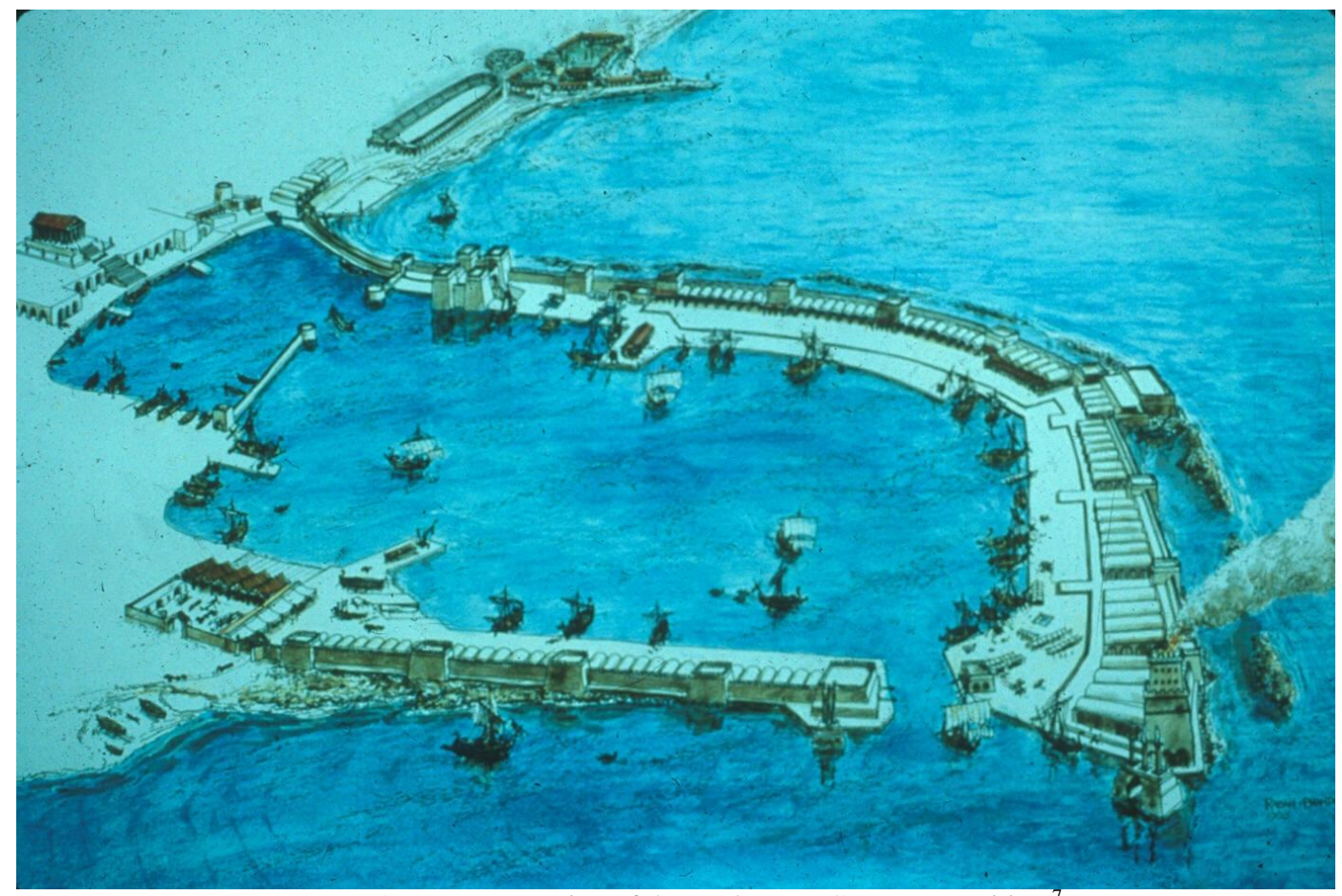

Figure 3. A reconstruction of the Harbour at Ceasarea Maritima ${ }^{7}$

The next phase was to protect the port from the power of the sea by building a low-lying structure to break the force of the waves called a prokomia. This was not a continuous structure. It ran parallel along the southern breakwater in sections. The function was to cause the waves to break early, to protect the main southern mole from the full force of the breakers and reduce the splash of seawater to make it possible to store dry goods in the harbour and to keep dry the accommodation for sailors (Raban, 2009). Archaeologists probing these external moles indicate that they were built of kurkar sandstone, and concrete blocks were used to reinforce the structures. The entrance into Sebastos was flanked by two massive towers. They were substantially constructed of concrete blocks as described above.

\section{Caesarea}

In addition to Sebastos, Herod built an entire city from the ground up in honour of his Roman patron calling it Caesarea. It was destined to become the second largest city in the country and later the Roman administrative capital. He built public entertainment facilities including a theatre and hippodrome/stadium using Roman innovative building techniques along with Jewish styles and craftsmanship in developing them into symbiotic buildings that showcased his imagination and design. Josephus describes the city thus

The city itself was called Caesarea, which of itself was built of fine materials, and was a fine structure. (JA 15.9.339)

So he dedicated the city to the province, and the haven to the sailors there; but the honour of the building he ascribed to Caesar, and named it Caesarea accordingly. (JW 1.21.414)

\footnotetext{
${ }^{7}$ http://www.stoa.org/hopper-images/2001.02/2001.02.0002.jpg, Accessed on 13.9.2018
} 


\section{Temple to Roma and Augustus}

Herod built a magnificent Temple dedicated to Roma and Augustus. It stood majestically at the top of the harbour and could be seen from a great distance out to sea and from the low-lying countryside. Josephus describes it:

And near to the mouth of the haven, upon an elevation, there was a temple for Caesar, which was excellent both in beauty and size; therein was a Colossus of Caesar, not less than that of Jupiter Olympus, which it was made to resemble. The other Colossus of Rome was equal to the Juno of Argos. (JW 1.21.7.414)

A natural ridge of kurkar sandstone was chosen which could be levelled, extended, and elevated. Walls of great square ashlar blocks were built to contain the soil fill which increased the size of the base (Holum, 2004). The podium on which the temple was built was $28.5 \mathrm{~m} \times 46.2 \mathrm{~m}$ in size, on which was constructed a massive building made from great ashlar blocks of kurkar sandstone quarried locally. This use of stone available within the immediate district which was a common element in Herodian structures at Masada, Jericho, and Herodium, could be plastered with stucco so that it appeared to be marble. Herod may not have had a specialised technical understanding of Roman temple building but he used his imagination and revolutionary vision to construct a monumental building that dominated the harbour, the city and the flat surrounding countryside (Kahn, 1996). It was a shining white building with Corinthian columns. A grand stairway led from the quay side to the temple with a second staircase that gave access to/from the city. There was a sacrificial altar at the foot of the main staircase located adjacent to the inner harbour. The temple contained two monumental statues of Roma and Augustus, created by Herod to give due deference to Augustus, his Roman patron.

\section{Water}

Josephus does not mention an aquaduct at Caesarea but the remains of a water system are in evidence. The system does bear evidence of different phases of building, modification, and repair but the older eastern aquaduct was dated to the Herodian era (Olami \& Peleg, 1977). There has been debate as to whether the aquaduct was built by Herod or sometime later (Patrich, 2011). Hydraulic plaster within the duct has been dated by some to the first century C.E. but there are conflicting assumptions among scholars. Could regional differences in the composition of hydraulic concrete be a reason for this hypothesis (Patrich, 2007; Netzer, 2006)?

No other water system has been uncovered at Caesarea. Herod would have needed an abundant water supply for the city being constructed and there were no significant fresh water supplies in the area. It is unlikely that he would have had his new city dependent for supply on wells in the local area or water collected in cisterns (Burrell, 2009).

Logically, the great aquaduct at Caesarea seems the most likely structure for supplying water to the Port-City (Mayerson, 1986). Herod had in many of his palaces applied great effort and expense in bringing water over great distances. Certainly, the Roman master builders would have had the knowledge and the experience to build such a system. The aquaduct piped water from a group of springs, particularly ein shuni which is located at the southern end of the Mount Carmel range of mountains at about eight kilometres northeast of the city (Netzer, 2006). The water was directed along covered channels into a large storage pool before being routed downwards towards the city. For the last five kilometers, a raised aquaduct ran along the coast. The builders imitated the arcades on the southern approaches to Rome (Roller, 1998). It was one of the finest aquaducts ever constructed in Judea. Herod imported new Roman technology to deliver water over a long distance. 


\section{City and Entertainment Facilities}

Herod created a well-planned city following a grid system for streets and sewers (Netzer, 2007).

Now there were continual edifices joined to the haven, which were also themselves of white stone; and to this haven did the narrow streets of the city lead, and were built at equal distances from one another. (JW 1.21.7.414)

The very subterranean vaults and cellars had no less of architecture bestowed on them than the buildings above ground. Some of these vaults carried things at even distances to the haven and to the sea; but one of them ran obliquely, and bound all the rest together, that both the rain and the filth of the citizens were together carried off with ease, and the sea itself, upon the flux of the tide from without, came into the city, and washed it all clean. (JA 15.9.340)

The street system was based on an orthogonal grid with north-south cardines and east-west decumani. The alignment of the city was defined by the harbour and the temple. Archaeological investigations confirmed that this grid system was used through all levels of occupation (Patrich, 2011). The Herodian road surface was of beaten yellow kurkar soil and unpaved. Streets were about $5 \mathrm{~m}$ wide and defined by buildings constructed directly onto the roads. There were no pavements or arcades and the edges of the streets were defined by a line of stones. Herod protected the city with a fortified wall which was $2.3 \mathrm{~m}$ thick, oval shaped, and equipped with round look-out towers.

Within the city walls there were public buildings. Josephus wrote about these in two separate places,

Herod also built therein a theater of stone; and on the south quarter, behind the port, an amphitheater also, capable of holding a vast number of men, and conveniently situated for a prospect to the sea. (JA 15.6.341)

The other buildings he put up, amphitheatre and theatre and agora, were worthy of the city's name. (JW 1.21.8.415)

Herod built a theatre and amphitheatre within the city walls. This was most unusual as entertainment areas were usually constructed outside cities in the Roman world. These constructions showed creativity, daring, and innovation. Herod based his designs on existing Roman models but brought new elements to his creations (Weiss, 2013). His interest in different cultures brought new traditions and customs to his kingdom that would influence generations to come (Weiss, 2013).

The theatre was a stone structure at a time when theatres were built in wood. Herod was the only king at that time who had built a theatre in stone! It was constructed facing the sea, a new and dramatic site capable of accommodating an audience of 3,500-4,000. It looked like a roman theatre but the decoration was unique and innovative. The orchestra floor was decorated with stucco containing geometrical patterns with a coloured band around the edge of the area. The only similar structure that is comparable is the theatre at Leptis Magna in North Africa dated 112 C.E. The front of stage (proscaenium) was painted with alternating niches of different shapes and depths and decorated with frescoes. The wall behind the stage (scaenae frons) was uniquely built of local kurkar sandstone, then plastered and stuccoed (following Herodian tradition), with an exceptional design, which has been found nowhere else, showing a central rectangular recess with curved niches on either side (Patrich, 2011; Weiss, 2013).

The second entertainment facility Josephus called an amphitheatre but scholars now say that it should be called a hippodrome-stadium (hippo-stadium). It was built on a stretch of sand to the south newly thrown up by the action of the sea against the harbour. It reveals an advance in design. It resembles a Roman circus but it had permanent seats and starting gates. It was a U-shaped construction which was built entirely of kurkar sandstone covered with white plaster. It was built on a north-south axis, containing an arena $300 \mathrm{~m} \times 50.5 \mathrm{~m}$ with 
comfortable seats (cavea) to the east, west, and south. It could hold 10,000 spectators. Herod created a multi-purpose structure capable of hosting gladiatorial, hunting occasions and athletics competitions. There was no central barrier (euripus) in the arena which differed from the Circus Maximus in Rome. Chariot races began from gated stalls in parallel lines and raced to the furthest turning point the (meta prima) following the Greek custom (Patrich, 2011; Weiss, 2013). Herod brought together in his entertainment areas ideas from Hellenistic and Hasmonean cities as well as the Roman world and integrated them into a single structure. Herod was the first to introduce public entertainment into Israel.

In preparation for the inaugural celebrations for his port-city extra accommodation was required for Herod's guests. The Promontory Palace was not suitable to host such an event (Ovadiah \& Peleg, 2009). A new more public palace extension was added on a separate terrace accessed by a staircase at the north-eastern end of the lower palace. It was orientated slightly differently from the lower palace. It was a rectangular construction built of kurkar sandstone with a large colonnaded courtyard $42 \mathrm{~m} \times 65 \mathrm{~m}$ in size. It had a throne room with underfloor heating, reception rooms, and bedrooms for Herod's visitors and a Roman bath house.

This he rebuilt in white stone and adorned with splendid palaces, as the best example of the grandeur of his spirit. (JW $1.408)$

In a most revolutionary arrangement the upper palace adjoined the hippo-stadium at the north-eastern corner and the theatre was easily accessible to the south of the palace.

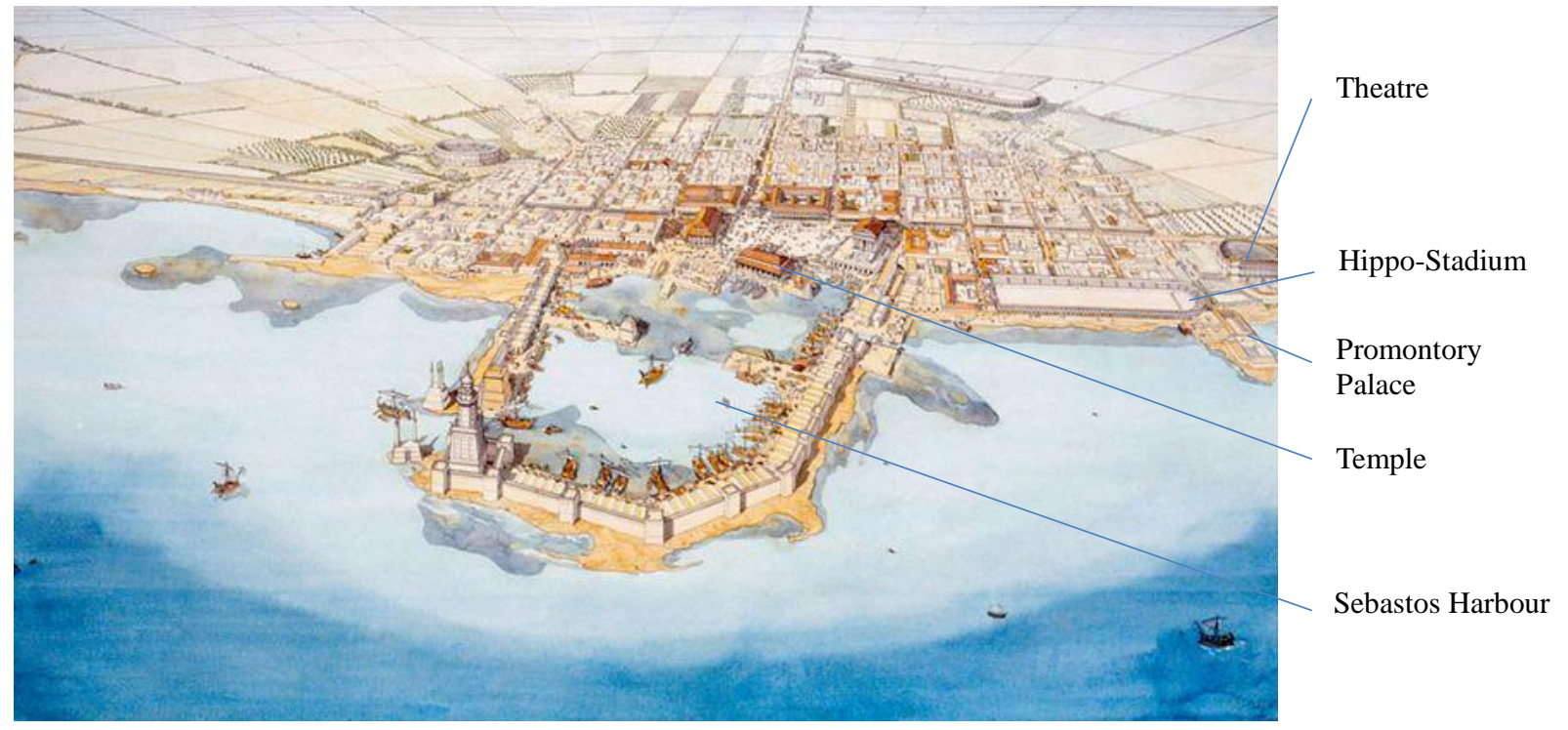

Figure 4. A stylised image of Caesarea Maritima. ${ }^{8}$

\section{Conclusion}

We know from Josephus that Herod the Great faced extreme challenges when he chose the exposed coast at Strato's Tower as the site for Sebastos Harbour and the city of Caeasarea. Israel's coastline around Caesarea Maritima today endures high winds and aggressive seas surging in onto this coastal area. Building out from a rugged shoreline into the open sea required an innovative approach in order to construct a man-made harbour. Herod had to confront many difficulties before his dream could become a reality. He had to finance the project,

\footnotetext{
${ }^{8}$ https://i.pinimg.com/736x/f8/2b/2a/f82b2a3ccdee1b800e96261ec31c5e94.jpg Accessed on 10.9.2018
} 
seek permission from Rome, find experienced master-builders, architects, and engineers, import raw materials from Italy (pozzalana) and Turkey (timber), create protection for the harbour and produce an anti-siltation regime. He overcame all the obstacles by putting in place all the necessary resources and building Sebastos in a very short time (22-10/9 B.C.E.) for such an enormous undertaking. Herod was in every sense an entrepreneur.

Sebastos Harbour is recognised by scholars as one of Herod's greatest engineering and architectural achievements. Totally, man-made the port was created with innovative technology-great concrete blocks were formed using cassions to shape massive breakwaters and towers. Moles were erected outside the seawalls to break the surge of the sea and reduce the splash. The remains of jetties and docks have been discovered but no vaults and warehouses. It is unlikely that Josephus was mistaken in his description, but it is possible that stones were looted over the years for building in the locality.

Josephus does not mention a water supply for Caesarea Maritima but there must have been one. The aquaduct is the most likely source but there is debate about when it was built. The aquaduct would not be out of place as a Herodian construction as Herod built aquaducts to some of his palaces.

Josephus records that Herod planned a walled city with streets, sewers, and public buildings but indications are that the urban area was not completed during his lifetime. The temple to Roma and Augustus stood in a commanding position at the top of the harbour, a monument to the king's imagination and creativity. The Promontory Palace built on two terraces is unique. Built out into the sea it was exceptional. The central focus of the lower palace was a swimming pool inventively located where a courtyard would normally have been sited. Josephus mentions that this palace was built before the harbour in his histography. The upper terrace was added before the inaugural celebration but he does not outline how the palaces were built.

Josephus mentions a theatre and an amphitheatre but does not tell us anything about them. Herod constructs these structures in a revolutionary way. First, he sited them within the city limits and adjacent to his palace. The theatre was built of stone, with exquisite decoration, at a time when they were generally built of wood. Josephus misnamed the amphitheatre. It was a Hippodrome-Stadium because of its size, shape, and function comparable with the Circus Maximus in Rome. The design was innovative. Built of kurkar sandstone and plastered, it incorporated permanent comfortable seats and starting gates and was used as a multifunctional entertainment facility.

Herod's life style spanned both east and west and his wide experience of architecture is emphasised in his creation at Caesarea Maritima. His personal ambition and interest in architecture conceived this project and carried it through to fruition. It shows spectacular innovation in construction, planning, and decoration.

\section{References}

Brandon, C. J. (2008). Roman structures in the sea: Sebastos, the Herodian harbor of Caesarea. Memoirs of the American Academy in Rome, Supplementary Volumes, 6, 245-254.

Brandon, C. J., Hohlfelder, R. L., Jackson, M. D., \& Oleson, J. P. (2014). Building for Eternity: The History and Technology of Roman Concrete Engineering in the Sea. Oxford: Exbow Books.

Burrell, B. (2009). Herod's Caesarea on Sebastos: Urban Structures and Influences. In D. Jacobson and N. Kokkinos (Eds.), Herod and Augustus: Papers Presented at the IJS Conference, 21st-23rd June 2005 (IJS Studies in Judaica) (pp. 217-233). Netherlands: Brill.

Burrell, B. (2014). The Legacies of Herod the Great. Near Eastern Archaeology, 77(2), 68-74.

Burrell, B., Gleason, K., \& Netzer, E. (1993). Uncovering Herod's Seaside Palace. Biblical Archaeology Review, 19(3), $50-55$.

Fisher, M. L., \& Alla, S. (1994). Josephus on the Use of Marble in Building Projects of Herod the Great. Journal of Jewish Studies, 45(1), 79-85. 
Hickey Morgan, M. (Trans.). (1914). Vitruvius: The Ten Books on Architecture. Cambridge: Harvard University Press.

Hohfelder, R. L., Brandon, C., \& Oleson, J. P. (2007). Constructing the Harbour of Caesarea Palaestina, Israel: New Evidence from the ROMACONS Field Campaign of October 2005. International Journal of Nautical Archaeology, 36(2), $409-415$.

Hohlfelder, R. L. (2000). Beyond Coincidence? Marcus Agrippa and King Herod's Harbor. Journal of Near Eastern Studies, 59(4), 241-253.

Holum, K. G. (2004). Caesarea's Temple Hill: The Archaeology of Sacred Space in an Ancient Mediterranean City. Near Eastern Archaeology, 67(4), 184-199.

Kahn, L. C. (1996). King Herod's Temple of Roma and Augustus at Caesarea Maritima. In A. Raban, \& K. Holum (Eds.), Caesarea Maritima: A Retrospective after Two Millennia (pp. 130-145). Leiden: E.J. Brill.

Martin, N. (2015). Towards a Better Understanding of Ancient and Modern Cement and Concrete. The Classical Outlook, 90(4), 130-133.

Mayerson, P. (1986). Choricius of Gaza on the Water Supply System of Caesarea. Israel Exploration Journal, 36(3/4), $269-272$.

Netzer, E. (1996). The Promontory Palace. In A. Raban, \& K. Holum (Eds.), Caesarea Maritima: A Retrospective after Two Millennia. Leiden: E.J. Brill.

Netzer, E. (2001). The Palaces of the Hasmoneans and Herod the Great. Jerusalem: Yad Ben-Zvi Press.

Netzer, E. (2006). The Architecture of Herod the Great Builder. Tubingen: Mohr Siebeck.

Netzer, E. (2007). The Ideal City of Herod the Great. In N. Kokkinos (Ed.), World of the Herods (pp. 77-78). Germany: Franz Steiner Verlag.

Netzer, E. (2008). The Architecture of Herod the Great Builder. Grand Rapids: Baker Academic.

Netzer, E. (2009). Palaces and the Planning of Complexes in the Herodian Realm. In D. Jacobson, \& N. Kokkinos (Eds.), Herod and Augustus: Papers Presented at the IJS Conference, 21st-23rd June 2005 (IJS Studies in Judaica) (pp. 171-180). Netherlands: Brill.

Olami, Y., \& Peleg, Y. (1977). The Water Supply System of Caesarea Maritima. Israel Exploration Journal, 27(2/3), 127-137.

Ovadiah, A., \& Peleg, R. (2009). The "Promontory Palace" in Caesarea Maritima and the Northern Palace at Masada. Revue Biblique, 116(4), 598-611.

Patrich, J. (2007). Herodian Caesarea: The Urban Space. In N. Kokkinos (Ed.), World of the Herods (pp. 93-129). Germany: Franz Steiner Verlag.

Patrich, J. (2011). Studies in the Archaeology and History of Caesarea Maritima. Leiden/Boston: Brill.

Raban, A. (1995). Sebastos, the Royal Harbour of Herod at Caesarea Maritima: 20 Years of Underwater Research. Marinarkeologsk Tidskrift, 1, 4-11.

Raban, A. (M. Artzy, B. Goodman, and Z. Gal, Eds.). (2009). The Harbour of Sebastos (Caesarea Maritima) in its Roman Mediterranean Context. Oxford: BAR International Series 1930.

Raban, A., \& Holum, K. (Eds.). (1996). Caesarea Maritima: A Retrospective after Two Millennia. Leiden: E.J. Brill.

Roller, D. (1998). The Building Program of Herod the Great. Berkerley/Los Angelos: University of California Press.

Schafer, P. (2003). The History of the Jews in the Greco-Roman World. London: Routledge.

Votruba, G. F. (2007). Imported Building Materials of Sebastos Harbour, Israel. International Journal of Nautical Archaeology, $36(2), 325-335$.

Weiss, Z. (2013). Buildings for Mass Entertainment in Herod's Kingdom. In S. Rozenberg, \& D. Mevorah (Eds.), Herod the Great: The King's Final Journey (pp. 224-239). Jerusalem: The Israel Museum.

Whiston, W. (1999). The New Complete Works of Josephus. Grand Rapids: Kregal Publications. 